\title{
ANTIMICROBIAL SUSCEPTIBILITY OF Streptococcus pneumoniae AND GENOTYPIC CHARACTERIZATION OF ERYTHROMYCIN-RESISTANT STRAINS IN PORTO ALEGRE, BRAZIL
}

\author{
F. T. Weber ${ }^{1}$, C. Dias ${ }^{2}$, M. da Costa ${ }^{3^{*}}$ \\ ${ }^{1}$ Programa de Pós Graduação em Microbiologia Agrícola e do Ambiente, Universidade Federal do Rio Grande do Sul, Porto \\ Alegre, RS, Brasil; ${ }^{2}$ Laboratório de Microbiologia e Parasitologia, Universidade Federal de Ciências da Saúde de Porto Alegre, \\ Porto Alegre, RS, Brasil; ${ }^{3}$ Departamento de Microbiologia, Instituto de Ciências Básicas da Saúde, Porto Alegre, RS, Brasil.
}

Submitted: June 21, 2008; Returned to authors for corrections: June 17, 2009; Approved: September 28, 2009.

\begin{abstract}
The antimicrobial susceptibility of 64 strains of $S$. pneumoniae obtained from three hospitals in Porto Alegre, Brazil, isolated between 2004 and 2005, was determined, using the agar-dilution method. The prevalence of resistant (intermediate and full resistance) strains to trimethoprim/sulphamethoxazole, penicillin, tetracycline, erythromycin, chloramphenicol, and ceftriaxone were $68 \%, 28 \%, 18 \%, 15 \%, 3 \%$, and 1\%, respectively. All strains were susceptible to vancomycin. Among 18 penicillin-resistant strains, 7 were resistant to at least two other antimicrobial drugs. All erythromycin-resistant strains, except one, contained the erm(B) and/or $m e f(\mathrm{~A} / \mathrm{E})$ genes, with a predominance of the former. The resistance rate to penicillin and erythromycin in Porto Alegre remained stable. The combination of trimethoprim/ sulphamethoxazole should not be recommended to treat pneumococcal infections, because of the high rate of resistant strains.
\end{abstract}

Key words: Streptococcus pneumoniae, drug resistance, erm(B), mef(A/E)

\section{INTRODUCTION}

Streptococcus pneumoniae is responsible for high rates of morbidity and mortality worldwide (14). This bacterium causes a wide range of pathologies such as pneumonia, meningitis, otitis media, bacteraemia, and other less-frequent infections such as endocarditis and arthritis (5). Pneumococcal infections are treated with penicillin as the first choice drug, and erythromycin is also frequently used. From 1980, pneumococcal strains began to show a significant increase in resistance rates to penicillin, impeding the control of infections (6). The resistance rate of $S$. pneumoniae varies with the locality or region studied, is influenced by the frequency and intensity of utilization, and empirical use of the antimicrobial drugs is frequent $(1,2,4)$. Because of this evolution of susceptibility of the strains, it is important to carry out constant monitoring of pneumoccocal-related infections. There are many mechanisms of resistance to antimicrobials and with macrolides, the $\operatorname{erm}(\mathrm{B})$ and $m e f(\mathrm{~A} / \mathrm{E})$ genes are responsible for the most-reported mechanisms of resistance to this class. The $\operatorname{erm}(\mathrm{B})$ gene is known to confer resistance to other antimicrobial classes and a high level of resistance to the macrolides $(16,20)$.

\footnotetext{
*Corresponding Author. Mailing address: Departamento de Microbiologia, Instituto de Ciências Básicas da Saúde, UFRGS, Rua Sarmento Leite, 500, sala 158, Porto Alegre, RS, Brazil. 90050-170.; Tel./Fax +55 513308 3445.; E-mail: $\underline{\text { mdcosta@ufrgs.br }}$
} 
Weber, F.T. et al.

In 2004 and 2005, 64 strains of S. pneumoniae were obtained from three hospitals in Porto Alegre. Identification of S. pneumoniae was based on observation of small mucoid colonies, $\alpha$-hemolytic, cell morphology (Gram-positive diplococci), and sensitivity to optoquine. These strains were isolated from different body fluids including blood, cerebrospinal fluid, and sputum.

Antimicrobial susceptibility was tested by the agardilution method according to the NCCLS recommendations, using 5\% sheep blood supplementation on Mueller-Hintonagar (10). The following antimicrobial drugs were included in the tests: penicillin, erythromycin, tetracycline, chloramphenicol, trimethoprim/sulphamethoxazole, ceftriaxone, and vancomycin (Sigma Chemical, Germany).

Erythromycin-resistant strains were screened for the presence of the $\operatorname{erm}(\mathrm{B})$ and $m e f(\mathrm{~A} / \mathrm{E})$ genes by $\mathrm{PCR}$, using primers and reaction conditions described elsewhere $(9,18)$. Amplifications were carried out in an Eppendorf thermocycler (Personal Mastercycler) using taq polymerase Invitrogen. DNA was extracted using enzyme treatment and phenolchloroform purifications (15). Ten susceptible strains to erythromycin and S. pneumoniae (ATCC49619) were used as negative controls in the PCR reactions. Two strains of $S$. pneumoniae, 2005 and 1721 (Laboratório de Microbiologia e Parasitologia, UFCSPA) were used as positive controls for the $\operatorname{erm}(\mathrm{B})$ and $m e f(\mathrm{~A} / \mathrm{E})$ genes respectively. All tests were repeated twice.

Table 1 summarizes the antibiotic profiles of $S$. pneumoniae strains resistant to one or more antimicrobials. Of 64 strains, 19\% were susceptible to all drugs tested. Resistance to vancomycin was not observed, in accordance with other studies (11).

Table 1. Antibiotic resistance patterns of 52 Streptococcus pneumoniae strains resistant to one or more antimicrobials.

\begin{tabular}{|c|c|c|c|c|}
\hline \multirow[t]{2}{*}{ Antibiotype $^{1}$} & \multirow{2}{*}{$\begin{array}{c}\text { Number of } \\
\text { resistant strains }{ }^{2}\end{array}$} & \multicolumn{3}{|c|}{ Number of strains with genotype } \\
\hline & & $\operatorname{erm}(\mathbf{B})$ & $\operatorname{mef}(\mathrm{A})$ & $\operatorname{erm}(\mathrm{B})+\operatorname{mef}(\mathrm{A})$ \\
\hline Sut & 22 & & & \\
\hline Sut,Er & 2 & 1 & 1 & \\
\hline Sut,Te & 4 & & & \\
\hline Sut,Ch & 1 & & & \\
\hline Sut,Pen & 10 & & & \\
\hline Sut,Pen,Te & 2 & & & \\
\hline Sut,Pen,Er & 2 & 2 & & \\
\hline Sut,Pen,Er, $\mathrm{Te}^{3}$ & 2 & 1 & & \\
\hline $\mathrm{Te}$ & 3 & & & \\
\hline $\mathrm{Er}$ & 2 & 1 & 1 & \\
\hline Er,Pen & 1 & & & 1 \\
\hline Er,Pen,Te,Ch,Cf & 1 & 1 & & \\
\hline
\end{tabular}


The association trimethoprim/sulphamethoxazole showed a high rate of resistance: $7 \%$ intermediate resistance $(2 / 38 \mu \mathrm{g} / \mathrm{mL})$ and $61 \%$ full resistance $(4 / 76 \mu \mathrm{g} / \mathrm{mL})$. Compared with a preceding study with strains in Brazil, there was an increased number of resistant strains, similar to the situation in other countries $(8,13)$ and should not be recommended to treat pneumococcal infections.

Forty-six strains $(72 \%)$ were susceptible to penicillin with a minimum inhibitory concentration (MIC) $\leq 0.06 \mu \mathrm{g} / \mathrm{mL}$. Among the resistant strains, 20\% showed intermediate resistance (between 0.12 and $1 \mu \mathrm{g} / \mathrm{mL}$ ) and $8 \%$ showed full resistance $(\geq 2 \mu \mathrm{g} / \mathrm{mL})$. These results showed that the local and national rates of penicillin resistance are stable compared to the results of other investigators, who reported rates of $26 \%$ (3, 22), and still can be considered a good option to control pneumococcal infection. As observed by other workers, among penicillin-resistant strains, multi-drug-resistant strains predominated (strains resistant to at least three classes of drugs, $39 \%, 7$ of 18 strains), compared with susceptible strains that showed concomitant resistance to a maximum of two drugs (Table 1) (21). It is important to note that patients infected whith penicillin-resistant strains stayed more days hospitalized compared to those infected with susceptible strains (19).

We observed a rate of tetracycline resistance below that reported in another study with Brazilian strains (32\%) (7). Seven strains showed intermediate resistance $(14 \%, 4 \mu \mathrm{g} / \mathrm{mL})$, and three strains showed full resistance $(4 \%, \geq 8 \mu \mathrm{g} / \mathrm{mL})$. Of these tetracycline-resistant strains, five were multi-resistant (Table 1). These results indicate that the empirical use of tetracycline in pneumococcal infections is limited.

With chloramphenicol, only $3 \%$ of the strains were resistant, with two fully resistant strains $(8 \mu \mathrm{g} / \mathrm{mL})$. Similarly low percentages were also observed in Belo Horizonte, Brazil (8) and in other countries (21).

Of the 64 strains, only $15 \%(\mathrm{~N}=10)$ showed full resistance to erythromycin $(\geq 1 \mu \mathrm{g} / \mathrm{mL})$. Of these resistant strains, four were susceptible to penicillin, and six were resistant (Table 2).
The rate of resistance to erythromycin was slightly increased, compared to results previously obtained with strains from Porto Alegre and other localities (2, 9). However, these numbers are below those reported in other countries, where rates up to $80 \%$ have been observed $(2,17)$.

These 10 resistant strains were analyzed to explore the possibility of a relationship between the observed resistance and the presence of the $\operatorname{erm}(\mathrm{B})$ and $m e f(\mathrm{~A} / \mathrm{E})$ genes. Six of these strains had $\operatorname{erm}(\mathrm{B})$, two had $m e f(\mathrm{~A} / \mathrm{E})$, one had both genes, and one did not have either gene (Tables 1 and 2). With these results, the relationship of these genes to the erythromycin resistance shown by these strains was confirmed. Strains that had erm(B) showed MICs between 2 and $\geq 8 \mu \mathrm{g} / \mathrm{mL}$, and those that had mef(A/E) showed MICs between 1 and $2 \mu \mathrm{g} / \mathrm{mL}$ (Table 2). Strains that had both genes showed MICs $\geq 8 \mu \mathrm{g} / \mathrm{mL}$, as did the strain that lacked these genes. In spite of the small number of erythromycin-resistant strains tested, almost all of the strains that had $\operatorname{erm}(\mathrm{B})$ showed elevated MICs, compared to those having mef(A/E). The erm(B) gene confers resistance to other classes of antimicrobials (streptogramines and lincosamines), affecting the therapeutic choice (16). The majority of strains that had erm(B) were penicillin-resistant. Similar observations were reported by other workers (Table 1 and 2) (16).

We observed that the rate of resistant strains to penicillin and erythromycin is stable compared to earlier results from studies in Brazil. The penicillin-resistant strains showed a tendency for multi-drug resistance, making it difficult to select an appropriate antimicrobial. In the association trimethoprim/sulphamethoxazole, a high prevalence of resistance was observed, and this combination should not be used to treat $S$. pneumoniae infections. In erythromycinresistant strains, a correlation between resistance and the presence of $\operatorname{erm}(\mathrm{B})$ and $m e f(\mathrm{~A} / \mathrm{E})$ was demonstrated, with the predominance of the former gene. Also, it is important to note that $30 \%$ of penicillin-resistant strains were also eritromycinresistant, and that almost all erytromycin-resistant strains had a $\operatorname{erm}(\mathrm{B})$ gene witch, besides the cross resistance to other drugs, 
Weber, F.T. et al.

leads to a high-level of resistance to such antimicrobials (12, 16).

Table 2. Minimum inhibitory concentration (MIC) with erythromycin-resistant strains of $S$. pneumoniae correlated with penicillin resistance.

Strains Erythromycin-resistant Penicillin-susceptibility

\begin{tabular}{llll}
\hline Gene & MIC & MIC
\end{tabular}

$(\mu \mathrm{g} / \mathrm{mL}) \quad(\mu \mathrm{g} / \mathrm{mL})^{1}$

\begin{tabular}{lcccc}
\hline 1614 & $e r m(\mathrm{~B})$ & 2 & 0.06 & $\mathrm{~S}$ \\
1574 & $e r m(\mathrm{~B})$ & 2 & 0.5 & $\mathrm{I}$ \\
1530 & $e r m(\mathrm{~B})$ & 4 & 0.25 & $\mathrm{I}$ \\
1603 & $e r m(\mathrm{~B})$ & 4 & 1 & $\mathrm{I}$ \\
1652 & $e r m(\mathrm{~B})$ & $>8$ & 0.03 & $\mathrm{~S}$ \\
1575 & $e r m(\mathrm{~B})$ & $>8$ & 2 & $\mathrm{R}$ \\
1558 & $e r m(\mathrm{~B}) / m e f(\mathrm{~A} / \mathrm{E})$ & $>8$ & 0.12 & $\mathrm{I}$ \\
1557 & $m e f(\mathrm{~A} / \mathrm{E})$ & 2 & 0.06 & $\mathrm{~S}$ \\
1514 & $m e f(\mathrm{~A} / \mathrm{E})$ & 1 & 0.06 & $\mathrm{~S}$ \\
1520 & -2 & $>8$ & 2 & $\mathrm{R}$
\end{tabular}

${ }^{1}$ I= intermediate resistance; $\mathrm{S}=$ susceptible; $\mathrm{R}=$ full resistance.

${ }^{2}$ Negative for both genes.

\section{REFERENCES}

1. Appelbaum, P.C. (2002). Resistance among Streptococcus pneumoniae: Implications for Drug Selection. Clin. Infect. Dis. 34, 1613-1620.

2. Borg, M.A.; Tiemersma, E.; Scicluna, E.; van de Sande-Bruinsma, N.; de Kraker, M; Monen, J.; Grundmann, H. (2009). Prevalence of penicillin and erythromycin resistance among invasive Streptococcus pneumoniae isolates reported by laboratories in the southern and eastern Mediterranean region. Clin. Microbiol. Infec. 15(3), 232-237.

3. Brandileone, M.C.C.; Di Fabio, J.L.; Vieira, V.S.D.; Zanella, R.C.; Casagrande, S.T.; Pignatari, A.C.; Tomaz, A. (1998). Geographic distribution of penicillin resistance of Streptococcus pneumoniae in Brazil: genetic relatedness. Microb. Drug Resist. 4(3), 209-217.

4. Gossens, H. (2009). Antibiotic consumption and link to resistance. Clin. Microbiol. Infec. 15(suppl.3), 12-15.
5. Hausdorff, W.P.; Feikin, D.R.; Klugman, K.P. (2005). Epidemiological differences among Pneumococcal serotypes. Lancet Infect. Dis. 5, 83-93.

6. Klugman, C. P. (1990). Pneumococcal resistance to antibiotics. Clin. Microbiol. Rev. 3, 171-96.

7. Levin, A.S.; Teixeira, L.M., Sesselogo, J.F.; Barone, A.A. (1996). Resistance of Streptococcus pneumoniae to antimicrobials in São Paulo, Brazil: clinical features and serotypes. Rev. Inst. Med. Tropical 38(3), 187-192.

8. Magalhães, A.P.G.O.; Pinto A.S. (2003). Antimicrobial resistance and serotyping of Streptococcus pneumoniae isolated from pediatric patients in Belo Horizonte, MG, Brazil. Braz. J. Microbiol. 34(3), 1517-1522.

9. Mendonça-Souza, C.R.V.; Carvalho, M.G.S.; Barros, R. R.; Dias, A. D.; Sampaio, J.L.M.; Castro, A.C.D.; Facklam, R.R.; Teixeira, L.M. (2004). Occurrence and characteristics of erythromycin-resistant Streptococcus pneumoniae strains isolated in three major Brazilian States. Microb. Drug Resist. 10(4), 313-320.

10. National Committee for Clinical Laboratory Standards. (2000). Methods for dilution antimicrobial susceptibility tests for bacteria that grow aerobically; Approved standard - 5th ed. NCCLS document M7-A5 (M100-S10), Wayne, Pennsylvania, USA.

11. Novak, R.; Henriques, B.; Charpentier, E.; Normark, S.; Tuomanen, E. (1999). Emergence of vancomicyn tolerance in Streptococcus pneumoniae. Nature 399, 590-593.

12. Rachdi, m.; Boubaker, I.B.B.; Moalla, S.; Smaoui, H.; Hammami, A.; Kechrid, A.; Redjeb, S.B. (2008). Phenotypic and genotypic characterization of macrolide resistant Streptococcus pneumoniae in Tunisia. Pathol. Biol. 56, 125-129.

13. Riedel S.; Beekmann S.E.; Heilmann K.P.; Richter S.S.; Garcia-deLomas J.; Ferech M.; Goosens H.; Doern G.V. (2007). Antimicrobial use in Europe and antimicrobial resistance in Streptococcus pneumoniae. Eur. J. Clin. Microbiol. Infect. Dis. 26, 485-490.

14. Rudan, I.; Boschi-Pinto, C.; Biloglav, Z.; Mulhollandd, K.; Campbelle, H. (2008). Epidemiology and etiology of childhood pneumonia. B. World Health Organ. 86, 408-416.

15. Sambrook, J.; Fritsch, E.F.; Maniatis, T. (1989). Molecular Cloning - A Laboratory Manual, $2^{\text {nd }}$ ed. Cold Spring Harbor Laboratory Press, New York.

16. Shortridge, V.D., Doern, G.V.; Brueggemann, A.B.; Beyer, J.M.; Flamm, R.K. (1999). Prevalence of macrolide resistance mechanisms in Streptococcus pneumoniae isolates from a multicenter antibiotic resistance surveillance study conducted in the United States in 19941995. Clin. Infect. Dis. 29, 1186-1188.

17. Song, J.; Chang, H.; Suh, J.Y.; Ko, K.S.; Jung, S.; Oh, W.S.; Peck, K.R.; Lee, N.Y.; Yang, Y.; Chongthaleong, A.; Aswapokee, N.; Chiu, C.; Lalitha, M.K.; Perera, J.; Yee, T.T.; Kumararasinghe, G.; Jamal, F.; Kamarulazaman, A.; Parasakthi, N.; Van, P.H.; So, T.; Keung, T. (2004). Macrolide resistance and genotypic characterization of Streptococcus pneumoniae in asian network for surveillance of resistant pathogens (ANSORP). J. Antimicrob. Chemother. 53, 457-463. 
18. Sutcliffe, J.; Grebe, T.; Tait-kamradt, A.; Wondrack. (1996). Detection of erythromycin-resistant determinants by PCR. Antimicrob. Agents Ch. 40(11), 2562-2566.

19. Vila-Corcoles, A.; Bejarano-Romero, F.; Salsench, E.; Ochoa-Gondar, O.; de Diego, C.; Gómez-Bartomeu, F.; Raga-Luria, X.; Cliville-Guasch, X.; Arija, V. (2009). Drug-resistance in Streptococcus pneumoniae among Spanish middle aged and older adults with community-acquired pneumonia. BMC Infect. Dis. http://www.biomedcentral.com/1471$2334 / 9 / 36$

20. Weilsblum, B. (1995) Erythromycin resistance by ribosome modification. Antimicrob. Agents Ch., 39, 577-585.

21. Whitney, C.G.; Farley, M.M.; Hadler, J.; Harrison, L. H.; Lexau, C.; Reingold, A.; Lefkowitz, L.; Cieslak, P.R.; Cetron, M.; Zell, E.R.; Jorgensen, J.H.; Schchat, A. (2000). Increasing prevalence of multidrugresistant Streptococcus pneumoniae in the United States. New Engl. J. Med. 343(26), 1917-1924.

22. Zettler, E.W., Scheibe, R.M., Dias, C.A.G., Santafé, P., Santos, D.S., Moreira, J.D.; Fritsher, C.C. (2006). Determination of penicillin resistance in Streptococcus pneumoniae isolates from Brazil by PCR. Intern. J. Infect. Dis. 10, 110-115. 